\title{
Быстро Е.A. \\ Проблема правового статуса самозанятого и пути его законодательного совершенствования
}

Международный юридический институт (МЮИ), Одинцовский филиал

(Россия, Одинияово)

doi: 10.18411/scienceconf-06-2021-16

\section{Аннотация}

В статье рассмотрены вопросы правового положения самозанятых и института самозанятости в Российской Федерации. Проанализированы законодательные нормы, регулирующие статус самозанятых и выявлены проблемы в его правовой регламентации, в том числе отсутствие официального закрепления термина «самозанятый» в Гражданском кодексе РФ. Предложены меры по совершенствованию правового положения самозанятого в России.

Ключевые слова: самозанятость, самозанятые, правовое положение самозанятого, трудовая деятельность, предпринимательство, предпринимательская инициатива.

\section{Abstract}

The article deals with the issues of the legal status of the self-employed and the institution of self-employment in the Russian Federation. The author analyzes the legislative norms regulating the status of the self-employed and identifies problems in its legal regulation, including the absence of an official definition of the term "self-employed" in the Civil Code of the Russian Federation. Measures are proposed to improve the legal status of the self-employed in Russia.

Keywords: self-employment, self-employed, the legal status of a self-employed, labor activity, entrepreneurship, entrepreneurial initiative.

Развитие информационных и трудосберегающих технологий, как во всем мире, так и в России, привело к тому, что в сфере трудоустройства появилась новая форма занятости - гибрид трудовой и предпринимательской деятельности, получивший название «самозанятость». Соответственно, лицо, выполняющее работы или оказывающее услуги в рамках данных занятий, стало называться «самозанятым».

Началом законодательного закрепления положения самозанятых послужило поручение Президента Российской Федерации В.В. Путина от 21 сентября 2016 года, в котором глава государства поставил задачей легализовать статус граждан, работающих без образования юридического лица и без найма работников. В дальнейшем Федеральным законом РФ от 26 июля 2017 года № 199-Ф3[3] в ст. 2 и ч. 1 ст. 23 Гражданского кодекса РФ[1] были внесены изменения, которые разрешили гражданам осуществлять предпринимательскую деятельность без наемных работников. А налоговое законодательство в перечень специальных налоговых режимов включило особый налог для самозанятых - налог на профессиональный доход (п. 2 ст. 18 Налогового кодекса РФ[2]). Последующие законодательные новеллы были направлены на отдельные аспекты регулирования самозанятости, в том числе, расширение видов деятельности самозанятых и списка субъектов РФ, в которых граждане получили право быть самозанятыми.

На основе рассмотренной законодательной базы в России достаточно активно началась регистрация граждан в качестве самозанятых. Проект по внедрению института самозанятости можно назвать достаточно успешным - по данным Федеральной службы государственной статистики РФ по состоянию на начало 2021 года в качестве самозанятых зарегистрировано более 1,8 млн человек. В 2020 году 
общая выручка от оказанных ими услуг составила около 200 млрд рублей, а сумма уплаченных налогов - почти 10 млрд рублей[8].

В то же время, несмотря на законодательное регулирование многих аспектов самозанятости, в отечественном законодательстве до сих пор отсутствует единый подход как к определению «самозанятости», так и разъяснение правового статуса самозанятого.

В среде ученых и практиков также не имеется единообразного понимания юридического положения самозанятых. В частности, не все авторы считают самозанятость предпринимательской деятельностью. Так, по мнению О.А. Белоусова, «данное суждение ошибочно, поскольку в действительности самозанятые работают «сами на себя»[6]. И далее он указывает, что термины «предпринимательство» и «самозанятость» смешиваются, тогда как самозанятые не являются субъектами предпринимательской деятельности.

Если исходить из нормативного понимания самозанятости, то данная точка зрения не совсем верна. В гражданском законодательстве отсутствует официальное понятие самозанятых и самозанятости, однако, если обратиться к положениям приказа Росстандарта от 9 июня 2016 года № 600-ст, которым с 1 марта 2017 года введен Межгосударственный стандарт[4], то мы увидим следующую формулировку: «самозанятый - человек, самостоятельно занятый трудом по оказанию услуг в рамках договоров гражданско-правового характера, в том числе в форме индивидуального предпринимательства». Следовательно, Стандарт говорит и о трудовой деятельности, и о предпринимательской деятельности. Соответственно данному определению, самозанятый уже не работает по найму у конкретного работодателя, а выполняет самостоятельную трудовую деятельность. При этом, законодатель не разрешает самозанятому нанимать собственных сотрудников, хотя и допускает осуществление самозанятости как предпринимательской деятельности.

Именно поэтому видится, что самозанятость включает в себя черты и трудовой деятельности, и предпринимательства, что дает возможность признать ее, как уже отмечалось выше, гибридной формой занятости, симбиозом трудовой и предпринимательской деятельности. Будучи самозанятым, лицо выполняет трудовые функции, но при этом также формирует в своей деятельности навыки начал предпринимательства - сам находит заказчиков и устанавливает с ними деловые связи, решает вопросы стоимости и порядка оплаты своей работы (услуг), уплачивает налоги. Приобретенный опыт самозанятой деятельности в дальнейшем, при желании самозанятого, может перерасти в полноценную предпринимательскую деятельность в форме индивидуального предпринимательства (ИП) или юридического лица (например, общество с ограниченной ответственностью).

Проведенный анализ законодательных норм, а также теоретических исследований о самозанятых и самозанятости[9], позволяет выделить ряд признаков, характеризующих правовое положение самозанятого гражданина:

- самостоятельное ведение деятельности самозанятым;

- осуществление самозанятой деятельности без привлечения наемных работников;

- получение нерегулярного дохода;

- осуществление видов самозанятой деятельности, предусмотренных законодательством;

- отсутствие трудовых договоров с работодателем.

Представляется, что перечень данных признаков дает полное право законодателю сформулировать официальное понятие самозанятого и закрепить его в нормах Гражданского кодекса РФ, благодаря чему лица, занимающиеся самозанятой деятельностью, получат полноценный правовой статус в гражданском законодательстве. Кроме того, четкое определение термина «самозанятый» в ГК РФ 
позволит разграничить правовое положение самозанятых и индивидуальных предпринимателей.

Также необходимо максимально расширить имеющийся список работ и услуг, которыми могут заниматься самозанятые. При этом, здесь можно и нужно опираться на опыт зарубежных государств, в практике которых институт самозанятости функционирует уже достаточно давно и имеет значимые успехи[5].

Дальнейшее реформирование статуса самозанятых, кроме того, видится в части упрощения механизма регистрации в качестве самозанятого. Кроме того, здесь является важным проведение широкой просветительской и курирующей деятельности со стороны государства. В частности, на уровне муниципальных центров занятости и налоговых служб видится возможным создание специальных отделов, функциями которых стала бы консультативная и практическая помощь, оказываемая гражданам при регистрации их в качестве самозанятых.

Самозанятые уплачивают налог на профессиональный доход, но при этом не являются плательщиками социальных взносов, а, соответственно, пенсионное страхование ими осуществляется в добровольном порядке. В то же время на практике для значимой части самозанятых такая деятельность является основной, а не дополнительным видом заработка. В связи с чем можно поставить вопрос о включении самозанятых в систему обязательного пенсионного страхования по их желанию. С одной стороны, это увеличит стоимость обязательных платежей в бюджет, поскольку к налогу добавится еще и страховой пенсионный взнос, но, с другой, предоставит самозанятым дополнительные социальные гарантии.

Подытоживая сказанное, следует отметить, что правовое положение самозанятых в России все еще находится в стадии законодательного оформления.

Уже немалое число граждан зарегистрировались в качестве самозанятых, однако проблема легализации лиц, работающих «на себя» все еще остается актуальной.

Пока еще непродолжительный период функционирования самозанятых свидетельствует о несомненных достоинствах исследуемого института для государства и общества, таких, как поступление дополнительных налоговых платежей в бюджет, официальная деятельность ранее нигде не оформленных граждан, развитие предпринимательской инициативы.

В связи с этим, очевидно, что политика государства в части закрепления правового положения самозанятых должна стать более активной и целенаправленной - требуются тщательная корректировка и систематизация правовой базы, регулирующей статус самозанятых и института самозанятости в целом.

$$
* * *
$$

1. Гражданский кодекс Российской Федерации (часть первая) от 30.11.1994 года № 51-Ф3 (ред. от 09.03.2021 года) // Собрание законодательства РФ. - 05.12.1994. - № 32. - Ст. 3301.

2. Налоговый кодекс Российской Федерации (часть первая) от 31.07.1998 года № 146-Ф3 (ред. от 17.02.2021 года) // Собрание законодательства РФ. - 03.08.1998. - № 31. - Ст. 3824.

3. Федеральный закон РФ от 26.07.2017 года № 199-Ф3 «О внесении изменений в статьи 2 и 23 части первой Гражданского кодекса Российской Федерации» // Собрание законодательства РФ. 31.07.2017. - № 31 (Часть I). - Ст. 4748.

4. Приказ Росстандарта от 09.06.2016 года № 600-ст «О введении в действие межгосударственного стандарта» // Охрана труда и социальное страхование. - 2017. - № 1.

5. Алиев О.М.О. Самозанятость в зарубежных странах: особенности налогообложения // Вестник Евразийской академии административных наук. - 2020. - № 2 (51). - С. 7-9.

6. Белоусов О.А. Регулирование вопросов самозанятых граждан: законодательный аспект // Сибирский экономический журнал. - 2021. - № 1 (18). - С. 4-6.

7. Ершова И.В., Трофимова Е.В. Самозанятость: к вопросу о правовой квалификации // В книге: Право и бизнес: правовое пространство для развития бизнеса в России. Коллективная монография. В 4-х томах. Отв. редактор С.Д. Могилевский [и др.]. - М., 2020. - С. 78-85.

8. Официальный сайт Федеральной службы государственной статистики РФ [Электронный ресурс]. Режим доступа: https://rosstat.gov.ru (дата обращения: 12.03.2021).

9. Покида А.Н., Зыбуновская Н.В. Регулирование деятельности самозанятых граждан // Вопросы государственного и муниципального управления. - 2020. - № 1. - С. 60-85. 